\title{
The Opinion of Auditors towards the Importance and Knowledge of Information Technology in Kuwait
}

\author{
Nabi Al-Duwaila ${ }^{1} \&$ Abdullah AL-Mutairi ${ }^{2}$ \\ ${ }^{1}$ Public Authority for Applied Education and Training (PAAET), Kuwait \\ ${ }^{2}$ Gulf University for Science and Technology, Kuwait \\ Correspondence: Abdullah AL-Mutairi, Gulf University for Science and Technology, Kuwait. E-mail: \\ mutairi.a@gust.edu.kw
}

Received: January 6, 2017

Accepted: January 30, 2017 Online Published: February 22, 2017

doi:10.5539/ijbm.v12n3p170

URL: https://doi.org/10.5539/ijbm.v12n3p170

\begin{abstract}
The current study attempts to explore the attitudes of the auditors towards the level of knowledge of Information Technology (IT) and its importance in Kuwait. To achieve these objectives, structure questionnaires were distributed among these auditors. The analysis covers 5 technology categories namely General Office Automation (GOA), Audit Automation (AA), Accounting Firm Office Automation (AFOA), E-Commerce Technologies (ECT) and System Design and Implementation (SDI).

It is found that the view of auditors to IT knowledge degree is lower than their view towards the importance of the technologies. The auditors have satisfactory knowledge only in GOA category and unsatisfactory knowledge for other four categories. It is also found that auditors rank AFOA category is the most significant category in terms of IT importance and knowledge and rank (ECT) the lowest category in terms of both importance and IT knowledge.
\end{abstract}

Keywords: Information technology knowledge, IT knowledge, IT importance, auditors, independent auditing, information system auditing, Kuwait

\section{Introduction}

The impact of accounting information systems on auditing process in business organizations has received great attention in finance literature, the main issue of this literature is to explore the effectiveness of Information Technology (IT) through gathering information, detecting the inefficiencies and identifying system controls designed.

Empirical studies provided inconclusive evidence regarding the level of IT of audit work in developing countries. They reported that the information systems audit is at the early phase and efficient use of audit technology instruments is important to the success of audit process. They also found that electronic spreadsheets, word processing and accounting software are placed as much- required skills to be obtained by accountants. Moreover, they demonstrated that auditors have satisfactory knowledge only in general office automation structure and unsatisfactory knowledge for E-commerce technologies. These findings, however, seem to be questionable for the markets such as the Gulf Co-operation Council (GCC) countries due to the difference in economic, political and cultural aspects.

The objective of this study is to present evidence on the attitudes of the auditors towards the level of knowledge of IT level and its importance in Kuwait. The motivation for the current study refers to there is no recent study explored the role of technology in audit quality from the perspectives of the auditors in Kuwait. It also assists practitioners and decision makers to obtain an interpretation of the nature and variables that might affect audit quality.

The remainder of the study is organized as follows. The following section presents a brief review of related literature and previous studies. Data collection and study methodology are explained in section three. While empirical results are discussed in the fourth section, a conclusion is offered in the final section.

\section{Related Literature and Previous Studies}

IT has a main impact on audit work (Okab, 2013). It represents all types of technology applied to transfer 
information in electronic shapes (Moorthy et al.; 2011). Technology is an instrument to solve its assignment in accounting system. It might define as a system computer to help users to achieve their tasks. IT leads to competitive advantage by removing time and space constraints (Moradi et al.; 2012). According to Al-Refaee and Siam (2013) the value of applying accounting information systems is to increase the efficiency and effectiveness of auditing process. Moorthy et al.; (2011) stated that audit methods and techniques should be developed to meet the shape of business controls.

In empirical literature, the level of IT of audit work has been examined in various countries (see for example, Norway: McKee, 2000. Taiwan: Chen, 2005; Chen et al.; 2005. Palestine: Humdona and Hamdan, 2008. USA: Janvrin et al.; 2008; Henderson et al.; 2013; Strong and Portz, 2015. USA and German: Prosch et al.; 2008. Malaysia: Ismail and Abidin, 2009; Moorthy et al.; 2011; Ilias et al.; 2012; Rosli et al.; 2012; Bahador and Haider, 2012. Indonesia: Islahuzzaman, 2010. Iran: Salehi and Husini, 2011; Moradi et al.; 2012; Abadi et al.; 2013.Jordan: Al-Hanini, 2011; Al-Kasswna, 2012; ALshbiel and AL-Zeaud, 2012; Al-Refaee and Siam, 2013; Okab, 2013; Allahawiah et al.; 2013. Nigeria: Ebimobowei et al.; 2013; Adeyemi et al.; 2014. Tanzania: Lotto, 2014. Libya: Tumi, 2014). The following section reviews in brief of these studies.

McKee (2000) selected 25 information technologies and examined the auditors' knowledge in Norway during the period 1998-1999. He found that most of the auditors have either no knowledge or relatively low levels of knowledge for the 25 information technologies surveyed. He noticed that participants believe that they have not received enough coverage of information technologies in their university study. As expected, McKee reported that the auditors of big firms have more knowledge of information technology than other firms.

Chen (2005) examined the level of IT of audit work in Taiwan. He found that accountants are skilled in the general computer and the professional accounting software skills. Chen et al.; (2005) distributed questionnaires among 595 CPA firms to examine the internet applications of accounting firms. They found that there are three major motives behind adopting accounting firms the internet. These motives are sharing internal resources, developing communication with customers and reducing the costs.

Humdona and Hamdan (2008) revealed that auditors employ IT in many audit process such as planning, controlling and documenting. They displayed that e-auditing assists in enhancing the evidence. Humdona and Hamdan suggested that executives of the profession need to foster the practice of e-audit in the audit processes by adopting new rules and improving the quality control criteria.

Janvrin et al. (2008) examined the use of audit IT and its perceived importance across several audit applications among 181 auditors. These auditors represent three types of firms namely Big 4, national regional and local firms. They found that auditors extensively employ range of audit applications including procedures, audit report writing, electronic work papers, internet search tools and sampling. They concluded that the use of auditors to IT technologies varies according to the firm size. Henderson et al.; (2013) found that knowledge of the IT risks and application controls have an important influence on the level of integrated internal audits. They concluded that mangers of the internal audit must assign the budget of training to increase IT application controls and its knowledge risks.

Strong and Portz (2015) examined students' attitudes at three Midwestern universities to determine their self-reported knowledge levels of 36 specific information technologies and difference in those IT knowledge levels among universities. They found that accounting students have a low level of self-perceived IT knowledge. They observed that students are not skilled in basic technologies even after finishing most of their undergraduate course work. They also found that there are significant differences in IT knowledge between the three universities in the study. Strong and Portz concluded that it is important to estimate IT knowledge and IT skill requirements for accounting students and develop a standard IT curriculum in accounting education.

Prosch et al. (2008) examined the attitudes of 2,500 United States and German auditing professionals to determine their self-reported knowledge levels of 36 information technologies. They found that there is a significant lack of knowledge in both countries in three of these five constructs. They also found that German auditors have significantly higher knowledge for the construct of networking and data transfer. They observed that U.S. auditors have significantly higher knowledge for three constructs: e-commerce technologies, general office automation, and audit automation technologies.

Ismail and Abidin (2009) used questionnaire to examine the level of IT of audit work in Malaysia. They found that the information systems audit is still at the infant stage. They found less than 22 percent of the participating firms use generalized audit software and only 16 percent provide information systems audit and assurance services. Also, they found that auditors have little information about advanced technologies in the context of audit work. Moorthy et al.; (2011) examined the role of IT in audit process. They found that valuable use of audit 
technology instruments is important to the success of audit process. However, it is only one phase toward realizing the auditing occupation. Ilias et al.; (2012) examined the different of perception toward teamwork skills (coordination, decision making, leadership, interpersonal skills, adaptability and communication) among final year accounting students. They found that the knowledge of accounting students of computer is moderate. Ilias et al. recommended that educations institutional need to develop the academic curricular in implementing the soft skills and technical skills in course.

Rosli et al. (2012) examined the acceptance of Computer-Assisted-Auditing Techniques and Tools (CAATTs) in audit firms. They found that acceptance of CAATTs seems to do not base on individual auditor's acceptance rather than contingent on organization's management, technological features as well as other external issues. Bahador and Haider (2012) examined the opinion of academicians towards the needed IT skills for accountants. They found that the most needed skills are spreadsheets, word processing and accounting software. They also found communication skills are required and delegation ones are the least important skills.

Islahuzzaman (2010) used questionnaire survey to examine the perception and knowledge of auditors towards IT audit service. The researcher found that the presence of IT audit service forms a new challenge for auditor profession. He also found that the auditors' perception towards IT audit is positive but they are lack of IT audit understanding and knowledge. Islahuzzaman suggested that the Indonesian Institute of Accountants should arrange profession standard of Indonesian IT audit.

Salehi and Husini (2011) examined the impact of IT on internal auditing. They found that auditors can increase their benefit and their duties with a high quality by using IT. They also found that using IT causes auditors to spend less time on probing and performing content tests and accuracy of mathematical calculations of office accounts rapidly. Moradi et al. (2012) used questionnaire among four types of auditors namely senior auditors, supervisors, senior supervisors, managers and working partners in Iranian firms of audit. They attempted to find out the level of their knowledge in IT. They found that auditors have adequate knowledge only in general office automation structure and inadequate knowledge for e-commerce technologies. They also found that the majority of auditors has insufficient knowledge of more advanced technologies especially technologies such as e-commerce and system design and installation. Moradi et al.; recommended that the auditing profession should cope with this matter that profession should match properly the society needs. Abadi et al.; (2013) examined the impact of IT on the efficiency of the accounting information systems in Iran hotel industry. They found that hotels have used new information technologies. Abadi et al.; provided evidence that the high-tech in accounting information systems add efficiency of the accounting process.

Al-Hanini (2011) examined the role of IT in enhancing the quality of auditing services in Jordan. He found that using IT enhances the quality of auditing services, planning for auditing, performing the analytical procedures and performing the auditing process and documentation. Al-Hanini also found that the auditors' inability to use IT in the auditing process is the main obstacles facing the use of IT in auditing process. Al-Kasswna (2012) examined the impact of IT on external audit fees. She found that IT level plays significant role in determining the fees of the audit process. ALshbiel and AL-Zeaud (2012) found that there is no statistically significant association between modern technology and the improved performance level of internal auditors in companies. Al-Refaee and Siam (2013) examined the impact of using IT on the independency and privacy of internal auditing in Islamic banks working in Jordan. They recommended providing enough information to all participants engaged in the auditing process. Allahawiah et al. (2013) confirmed that the influence of IT is clear on knowledge management practices. They suggested that the company management should update its employees by recent technology to reach work speed and obtaining satisfactory information. Okab (2013) examined the role of the professional specialty of external auditor in IT for improving the quality level of the external audit. She found that the external auditor is aware of the concept of the professional specialty in IT when he or she employs audit services. Okab added that the professional specialty seems to improve the quality level of audit services in Jordanian banks.

Ebimobowei et al. (2013) examined the use of IT in audit practice in the Niger Delta of Nigeria. They provided evidence that IT has become a favourable choice for auditors in developing business environment and an effective instrument to enhance the productivity and audit process. Ebimobowei et al.; concluded that professional accountants should improve their knowledge of IT and the process of computer accounting audit. Adeyemi et al. (2014) examined the opinion of compliance personnel towards the implementation of audit technology tools. They found that both internal auditors and audit department seem to do not obtaining considerable value of offered instruments. They observed that most internal audit departments and units seem to do not have official strategies and plans for combining technology in their internal audit practices. Adeyemi et al.; concluded that training costs and the lack of senior management support are the most causes behind impeding 
the use of technology tools.

Lotto (2014) examined the impact of IT on internal auditing in Tanzanian organizations. He found that the internal audit profession in Tanzania lags behind in effectively using IT to support their duties. He also found that the increase in number of CPAs holders in organizations did not improve the level of technology in the internal audit departments. Lotto concluded that internal auditors should educate executives about the existence of effective controls within the organization's IT infrastructure to improve overall efficiency, reliability, and performance of IT systems.

Tumi (2014) examined the attitudes of auditors in Libya towards the use of computer assisted audit techniques (CAATs) or continuous auditing (CA). The researcher found that auditors look at CAATs and CA as a fruitful influence on the audit process. However, He noticed that auditors do not utilize CAATs heavily and rarely use CA. He observed that the high costs contained seem to be main elements to impede auditors from using CAATs.

In the GCC region, there are few studies have been conducted to study the impact of IT on audit process (see for example, Saudi Arabia: Abu-Musa, 2008. United Arab Emirates (UAE): Majdalawieh and Zaghloul, 2009. Bahrain: Alqatanani and Hezabr, 2015). A brief review of these studies is offered in the following section.

Abu-Musa (2008) examined the effect of emerging IT on the activities of internal auditors (IAs). He found that there is a positive relationship between IAs' IT evaluations and the audit purposes and organizational features in the Saudi situation. He concluded that IAs should develop their knowledge and skills of Computerized Information Systems (CIS) as an attempt to reach the target of planning, directing, supervising and reviewing the work performed.

Majdalawieh and Zaghloul (2009) examined the various elements of the Information System (IS) audit universe that is constituted from: infrastructures, applications, and IT management in UAE context. They found that the role of IS auditors in lessening in applications and infrastructures audits is reinforcing in the arena of IT management audits.

Alqatanani and Hezabr (2015) examined the role of IT in audit process. They found that there is lack of sufficient level of awareness among auditors for auditing strategies in light of IT. They also found that there is a lack of confidence in electronic programs, the fear of data loss and the inability to maintain data protection. Alqatanani and Hezabr concluded that there is a need to increase the level of awareness and knowledge of audit strategies of IT in the Kingdom of Bahrain.

It is appeared that there is limit number of empirical studies in GCC region. This implies a need for empirical investigation in different place of country to increase our understanding of the attitudes of the auditors towards the level of knowledge of IT such as Kuwait environment which attributed a rich country. Therefore, the current study is conducted.

\section{Data Collection and Study Methodology}

The current study adopted a structured questionnaire to gather data about the attitudes of the auditors towards the level of knowledge of IT level and its importance in Kuwait. The questionnaire includes two sections, while the first section covers general information about the participant; the second section of the questionnaire consists of 31 IT items that are used by Kuwaiti auditors.

The questionnaire was improved by the investigators according to the objective of the study. The questionnaire has been reviewed by some particular professors to ensure its validity. The questionnaire was adapted according to their advices and suggestions. Furthermore, the questionnaire was piloted among auditors in Kuwait. As a result, some questions were revised as an attempt to be understood by the participants.

Then, the questionnaires were distributed to 100 auditors. It covers five categories including partners, audit managers, supervisors, senior auditors and auditors operating in the audit firm. 70 participants have completed the questionnaire resulting 70 percent response rate. To estimate the reliability of the collected data, a reliability test was checked, and the Cronbach's Alpha for the collected data showed 0.81. According to Al-Kasswna (2012) 0.70 or more Cronbach's Alpha value is adequate to certify data reliability in such study. The collected data inserted in Statistical Package for Social Sciences (SPSS) file for analysis. Descriptive statistics were carried out to test the viewpoints of the auditors towards the level of knowledge of IT and its importance in Kuwait.

\section{Findings}

\subsection{Respondents' Background}

Table 1 summarizes background statistics of the respondents who participated in the survey. The table shows that the most of the respondents ( 71 percent) are Kuwaitis and the rest (29 percent) are non-Kuwaitis. It also indicates 
that the most of the respondents ( 86 percent) are male, 14 percent of the respondents are female which indicates the low rate of working women in audit firms.

Table1. Informational background about the respondents

\begin{tabular}{|c|c|c|}
\hline Characteristics & Frequency & Percent \\
\hline \multicolumn{3}{|l|}{ 1)Gender } \\
\hline a) Male & 60 & 86 \\
\hline b)Female & 10 & 14 \\
\hline \multicolumn{3}{|l|}{ c) } \\
\hline \multicolumn{3}{|l|}{ 2)Nationality } \\
\hline a) Kuwaiti & 50 & 71 \\
\hline b)Non-Kuwaiti & 20 & 29 \\
\hline \multicolumn{3}{|l|}{ 3)Level of education } \\
\hline a) University Degree & 40 & 57 \\
\hline b)Master level & 20 & 29 \\
\hline c) Doctorate level & 10 & 14 \\
\hline \multicolumn{3}{|l|}{ 4)Auditor's experience } \\
\hline a) from 1 to 3 years & 10 & 14 \\
\hline b)from 3 to 7 years & 20 & 29 \\
\hline c) More than 7 years & 40 & 57 \\
\hline \multicolumn{3}{|l|}{ 5) Participant age } \\
\hline a)Less than 30 years old & 15 & 21.5 \\
\hline b)from 30 to 50 year old & 40 & 57 \\
\hline c) More than 50 year old & 15 & 21.1 \\
\hline \multicolumn{3}{|l|}{ 6)Category of the firm } \\
\hline a) Big Four and its affiliates & 7 & 10 \\
\hline b)Non-Big Four & 63 & 90 \\
\hline \multicolumn{3}{|l|}{ 7)Occupation } \\
\hline a) Partner & 5 & 7 \\
\hline b)Audit manager & 7 & 10 \\
\hline c) Supervisor & 13 & 19 \\
\hline d)Senior auditor & 30 & 43 \\
\hline e) Auditor & 15 & 21 \\
\hline
\end{tabular}

The table reveals that more than 55 percent of participants' age is from $30-50$ years old which is fitting with the age groups of the nature of the audit work. It also displays that the majority of participants have experience more than 7 years and more than 40 percent are senior auditors suggesting that they have experience and able to provide considerable answers to the questions. Further, the table demonstrates that the most of the auditors have a university degree or above. It suggests the high academic qualifications in business-related studies are employed in auditing work in Kuwait.

Table 1 shows that 90 percent of the participants are operating with local audit firms, while the remaining 10 percent are operating with the big-four firms. The auditing firms which are affiliated by Big Four Accounting firms are Al-Aiban and Al-Osami auditing firm by Ernst \& Young (E\&Y); Al-Wazzan auditing firm by Pricewaterhouse- Coopers (PWC); Safi Al-Muta auditing firm by KPMG; and Al-Fahed and Al-Marzook auditing firm by Deloitte Touche \& Tohmatsu.

\subsection{Importance of Information Technology}

Number of technology items was listed in the questionnaire and the participants were requested to rank their importance on auditing process. They were requested to provide their degree of agreement about each of them. The result of the analysis is reported in table 2. It shows that the mean value of the auditors' perception towards the importance of technology items extents from 2.5 to 4.71 and their perception towards the knowledge of information technology items extents from 2.1 to 3.86. It seems that these items have insignificant impact on the audit work, so their knowledge regarding the technology items is much less. 
Table 2. Mean Ratings and Rankings of importance and knowledge of IT

\begin{tabular}{|c|c|c|c|c|c|c|c|}
\hline \multirow[b]{2}{*}{$\mathbf{A}$} & \multirow{2}{*}{$\begin{array}{l}\text { Category/ Technology } \\
\text { General Office Automation }\end{array}$} & \multicolumn{3}{|c|}{ Importance } & \multicolumn{3}{|c|}{ Knowledge } \\
\hline & & Mean & Rank & S.D & Mean & Rank & S.D \\
\hline 1 & Word processing & 4.71 & 1 & 0.488 & 3.86 & 1 & 1.464 \\
\hline 2 & Electronic Spreadsheets & 4.29 & 2 & 0.488 & 3.81 & 2 & 1.464 \\
\hline 3 & E-mail & 4.14 & 5 & 1.464 & 3.79 & 3 & 1.676 \\
\hline 4 & Internet Search and Retrieval & 3.43 & 27 & 1.397 & 3.57 & 4 & 1.512 \\
\hline 5 & Image Processing & 3.0 & 30 & 1 & 3.14 & 7 & 1.215 \\
\hline 6 & Electronic Presentations & 3.71 & 20 & 0.756 & 3 & 14 & 1.414 \\
\hline B & Accounting Firm Office Automation & & & & & & \\
\hline 1 & Time Management \& Billing Systems & 4.12 & 6 & 0.69 & 3 & 15 & 1.633 \\
\hline 2 & Small Business Accounting software & 4.28 & 3 & 0.756 & 2.86 & 20 & 1.464 \\
\hline 3 & Tax Return Preparation Software & 4 & 9 & 0.577 & 2.88 & 19 & 1.633 \\
\hline $\mathbf{C}$ & Audit Automation & & & & & & \\
\hline 1 & General Audit Software & 4.1 & 8 & 0.816 & 3.12 & 8 & 1.574 \\
\hline 2 & Expert Systems & 3.86 & 14 & 0.69 & 2.71 & 24 & 1.38 \\
\hline 3 & Electronic Working Papers & 3.84 & 15 & 1.069 & 3.11 & 9 & 1.574 \\
\hline 4 & Embedded Audit Modules/Real-time Audit Module & 3.82 & 16 & 0.9 & 3.29 & 5 & 1.704 \\
\hline D & E- Commerce Technology & & & & & & \\
\hline 1 & Encryption Software & 3.41 & 28 & 0.976 & 2.68 & 26 & 1.254 \\
\hline 2 & Digital Communications & 3.5 & 26 & 1.512 & 3.09 & 11 & 1.464 \\
\hline 3 & Firewall Software/Hardware & 3.69 & 22 & 0.488 & 2.9 & 18 & 1.528 \\
\hline 4 & EDI-Traditional & 3.94 & 12 & 1.155 & 3.2 & 6 & 1.704 \\
\hline 5 & EDI-Web Based & 3.64 & 24 & 0.951 & 3.07 & 13 & 1.773 \\
\hline 6 & Wireless Communications & 3.70 & 21 & 1.254 & 2.95 & 16 & 1.732 \\
\hline 7 & Intrusion Detection \& Monitoring & 3.14 & 29 & 0.69 & 3.05 & 12 & 1.574 \\
\hline 8 & Internal Network Configurations & 4.26 & 4 & 0.756 & 2.92 & 17 & 1.633 \\
\hline 9 & External Network Configurations & 3.94 & 12 & 1.528 & 2.62 & 28 & 1.38 \\
\hline 10 & Agent technologies & 2.49 & 31 & 1.09 & 2.1 & 31 & 1.1 \\
\hline $\mathbf{E}$ & Systems Design and Implementation & & & & & & \\
\hline 1 & Database Search \& Retrieval & 3.99 & 10 & 1.528 & 3.1 & 10 & 1.773 \\
\hline 2 & Simulation Software & 3.96 & 11 & 0.816 & 2.84 & 21 & 1.574 \\
\hline 3 & Flowcharting/ Data Modelling & 3.79 & 18 & 0.69 & 2.65 & 27 & 1.38 \\
\hline 4 & Computer Aided Systems Engineering Tools & 3.57 & 25 & 1.272 & 2.57 & 29 & 1.272 \\
\hline 5 & Cooperative Client/ Server Environment & 3.77 & 19 & 1.069 & 2.5 & 30 & 1.272 \\
\hline 6 & Workflow Technology & 3.66 & 23 & 0.951 & 2.7 & 25 & 1.496 \\
\hline 7 & Database Design \& Installation & 3.80 & 17 & 1.069 & 2.8 & 22 & 1.574 \\
\hline 8 & Test Data & 4.11 & 7 & .90 & 2.75 & 23 & 1.464 \\
\hline
\end{tabular}

It is obvious that nine of technology items obtained a mean value of 4.0 and above suggesting the most important items by the participants. The table demonstrates that these technology items are word-processing (4.71), electronic spreadsheet (4.29), small business accounting software (4.28), internal network configurations (4.26), E-email (4.14). The possible explanation might refer to the fact that these items are simple and common used by auditors. The finding is on line with the finding obtained by previous empirical studies that stated word-processing, electronic spreadsheet and email are the most important technology items used by auditors in Malaysia (Ismail \& Abidin, 2009) and Iran (Moradi et al., 2012).

The table also shows that seventeen technology items obtained a mean value between 3.50 and 3.99, suggesting moderate important by the responding auditors. These technology items are database search \& retrieval; simulation software; EDI-traditional; external network configurations; expert systems; electronic working papers; embedded audit modules/real-time audit module; database design \& installation; flowcharting/ data modelling; cooperative client/ server environment; electronic presentations; wireless communications; firewall software/hardware; workflow technology; EDI-Web based; computer aided systems engineering tools; digital communications.

Moreover, the table 2 shows that the remaining four technology items are perceived less important by the participants. These technology items obtained a mean value of below 3.50. These technology items are internet 
search and retrieval (3.43); encryption software (3.41); intrusion detection \& monitoring (3.14); image processing (3.0). Furthermore, one technology item obtained a mean value below 2.50; this technology item is agent technologies (2.49) which is consistent with the findings obtained by Moradi et al.; (2012) in Iran.

\subsection{Knowledge of Information Technology}

Number of technology items was listed in the questionnaire and the participants were requested to rank their own knowledge. They were requested to provide their degree of agreement about each of them. The finding of the analysis is described in table 2. It shows that the mean score of the knowledge of information technology items spans from 2.1 to 3.86 .

Table 2 shows that the mean score for the self-perceived IT knowledge items spans from 2.1 to 3.86 . It is clear that the mean value of the perception of the importance of technology is lower than the mean value of their perception towards the knowledge of IT (2.49 to 4.71). In other words, the auditors perceived their IT knowledge is less than what they perceived as important in their audit work. The possible explanation interprets the fact that knowledge of all information technologies is not necessary for auditors to accomplish their audit duties. Also, auditors might have inadequate attention of information technologies in their study at college or university. The finding is consistent with the results reached by previous empirical studies that reported there is lacked significant knowledge among auditors in IT such as Prosch et al.; (2008) in USA and German; Ismail and Abidin, (2009) in Malaysia and Moradi et al.; (2012) in Iran.

Table 2 also demonstrates that four information technology items registered a mean value above 3.50. These items are word-processing (3.86), electronic spread sheet (3.81), email (3.79), and internet search and retrieval (3.57). The finding suggests that the participants perceived they have good knowledge on only 4 technologies. The possible explanation might reflect the fact that these items are simple and commonly used by auditors. Furthermore, eleven technology items registered a mean value between 3.00 and 3.50, while the other remaining 16 technologies registered a mean value below 3.00.

The least IT knowledge possessed by the participants are agent technologies (2.1), cooperative client/server environment (2.5), computer aided systems engineering tools (2.57), external network configurations (2.62), flow charting/data modeling (2.65), encryption software (2.68), work flow technology (2.7), expert systems (2.71), test data (2.75), database design and installation (2.8), simulation software (2.84), small business accounting software (2.86), tax return preparation software (2.88), firewall software/hardware (2.9), internal network configurations (2.92), wireless communications (2.95). It suggests that these technology items are not really essential for audit process. The finding is consistent with the results reached by Ismail and Abidin, (2009) in Malaysia that demonstrated knowledge of all individual information technologies is not compulsory for practised judgment. Moreover, the finding is on line with the results obtained by Greenstein and McKee (2004) that both educators and practitioners had a relatively low level of knowledge for e-commerce and audit automation.

\section{Conclusion}

In the current study, an attempt was achieved to identify the attitudes of the auditors towards the level of knowledge of IT and its importance in Kuwait. To achieve the target of the study, 70 questionnaires were acceptable for analysis from 100 distributed ones. The reliability inspection was performed to estimate the internal consistency of construct validity. The stability of the questionnaire was confirmed by the Cronbach's alpha coefficient, where the output of the test showed that the reliability coefficient was above 0.80 .

It is obvious that auditors recognized that their knowledge in IT is less than what they recognized as important in their audit work. There is an agreement among auditors regarding the importance of IT in audit process; however, there is variation among them regarding their knowledge. The analysis demonstrated that auditors employed in firm auditing affiliated by Big 4 firms are more likely to use audit applications. They rate their importance higher than auditors working in firm auditing affiliated by local for several applications, including audit planning, electronic work papers, internal control evaluation and sampling.

The study showed that auditors have considerable knowledge in 13 technologies and have inconsiderable knowledge in 18 remaining technologies. The strength side of auditors takes place on general office automation, accounting firm office automation and audit automation while the weakness side takes place on e-commerce and system design and installation. Therefore, it is important for auditing profession to enhance the requisite skills of IT among auditors in Kuwait.

It is clear that there is disagreement among auditors' perception between importance and knowledge items of IT for advanced technologies like database design and installation suggesting insignificant role of these items on 
audit work. Therefore, there is a need to develop IT infrastructure and specially these information technology items to be used by the auditor who should have the least base of knowledge to audit computerized accounting systems.

The major contribution of the study is to explore the significant changes of auditing profession that considers challenge for decision makers in developing IT's skills of auditors in Kuwait. As a result, the auditors should have the main knowledge and skills of auditing computerized accounting systems in audit process.

In conclusion, the study attempted to identify the attitudes of the auditors towards the level of knowledge of IT level and its importance in Kuwait. The findings of this study might be repeated in other GCC countries particularly those with similar IT development. Moreover, another study might explore whether the auditor's use of IT is the interest of individual auditor or firm strategy.

\section{Acknowledgments}

This work was supported by a grant from Public Authority for Applied Education and Training (PAAET), research project no. BS-15-05. Special thanks to our academic colleagues for their productive comments and kindly guidance during the paper work.

\section{References}

Abadi, A., Kermani, N., Zoqian, M., Mollaabbasi, H., Abadi, R., Abadi, M., Fanaean, H., \& Farzani, H. (2013).The influence of information technology on the efficiency of the accounting information systems in Iran hotel industry. International Research Journal of Applied and Basic Sciences, 4(8), 2408-2414

Abu-Musa, A. (2008). Information technology and its implications for internal auditing: An empirical study of Saudi organizations. Managerial Auditing Journal, 23(5), 438-466. http://dx.doi.org/10.1108/02686900810875280

Adeyemi, S., Mohammed, A., Ogundeji, M., \& Oladipupo, M. (2014). Audit technology tools and business process assurance: Assessment of auditors' perspective in Nigeria. Universal Journal of Industrial and Business Management, 2(4), 93-102. http://dx.doi.org/10.13189/ ujibm.2014.020401

Al-Hanini, E. (2011). The role of using information technology in enhancing the quality of auditing services in Jordan- empirical study at auditing offices and companies working in Jordan. An-Najah University Journal for Research-Humanities, 25(8), 2199-2230.

Al-Kasswna, R. (2012). The impact of information technology on external audit fees-A field study in the Hashemite Kingdom of Jordan. European Journal of Business and Management, 4(14), 92-102

Allahawiah, S., Al-Mobaideen, H., \& Al-Nawaiseh, K. (2013). The impact of information technology on knowledge management processes: An empirical study in the Arab Potash Company. International Business Research, 6(1), 235-252. http://dx.doi.org/10.5539/ibr.v6n1p235

Alqatanani, Kh., \& Hezabr, A. (2015). To what extent the auditors in the Kingdom of Bahrain recognize auditing strategies in the light of information technology and what is its impact on the audit? A field study. International Journal of Economics, Commerce and Management, 3(5), 698-711.

Al-Refaee, Kh., \& Siam, A. (2013). The effect of using information technology on increasing the efficiency of internal auditing systems in Islamic banks operating in Jordan. Research Journal of Finance and Accounting, 4(9), 110-117

ALShbiel, S., \& AL-Zeaud, H. (2012). Management support and its impact on performance of internal auditors at Jordanian public industrial shareholding companies. Global Journal of International Business Research, $5(5), 52-64$.

Bahador, K., \& Haider, A. (2012). Information technology competencies for Malaysian accountants - An academic's prespective, 23rd Australasian Conference on Information Systems Information Technology Competencies for Accountants 3-5 Dec 2012, Retrieved from https://dro.deakin.edu.au/eserv/DU:30049112/kubahador-informationtechnology-2012.pdf

Bierstaker, J.; Burnaby, P., \& Thibodeau, J. (2001). The impact of information technology on the audit process: An assessment of the state of the art and implications for the future. Managerial Auditing Journal, 16(3), 159-164. http://dx.doi.org/10.1108/02686900110385489

Chen, M., Tseng, C., \& Chang, J. (2005). A survey investigation into the use of the Internet among accounting firms. International Journal of Management, 22(4), 649-660. 
Chen, Y. (2005). Prepare for e-generation: The fundamental computer skills of accountants in Taiwan. Journal of American Academy Business, 7(1), 131-135.

Ebimobowei, A., Ogbonna, G., \& Enebraye, Z. (2013). Auditors' usage of computer assisted audit tools and techniques: Empirical evidence from Nigeria. Research Journal of Applied Sciences, Engineering and Technology, 6(2), 187-195

Greenstein, M., \& McKee, T. (2004). Assurance practitioners' and educators' self-perceived IT knowledge level: An empirical assessment. International Journal of Accounting Information Systems, 5(2), 213-243. http://dx.doi.org/10.1016/j.accinf.2004.04.002

Henderson, D., Davis, J., \& Lapke, M. (2013). The effect of internal auditors' information technology knowledge on integrated internal audits. International Business Research, 6(4), 147-162. http://dx.doi.org/10.5539/ibr.v6n4p147

Humdona, T., \& Hamdan, A. (2008). The extent of the use of information technology in the process of auditing (E-Auditing) in Palestine, and its effect on the quality of the evidence to support the audit opinion of the neutral prepared on the financial statement. Islamic University Periodical-Human Studies, 16(1), 913-958

Ilias, A., Razak, M., Yunus, N., \& Razak, S. (2012). How accounting students perceived towards teamwork skills. Journal of Education and Vocational Research, 3(12), 387-398

Islahuzzaman. (2010). Auditors' perception towards information technology. Retrieved from http://repository.widyatama.ac.id/xmlui/bitstream/handle/123456789/1759/content.pdf?sequence

Ismail, N., \& Abidin, A. (2009). Perception towards the importance and knowledge of information technology among auditors in Malaysia.Journal of Accounting and Taxation, 1(4), 61-69.

Janvrin, D., Bierstaker, J., \& Lowe, J. (2008). An examination of audit information technology use and perceived importance. Accounting Horizons, 22(1), 1-21.

Lotto, J. (2014). Examining the impact of information technology on internal auditing effectiveness in Tanzanian organizations. Time Journals of Social Sciences, 2(3), 13-23.

Majdalawieh, M., \& Zaghloul, I. (2009).Paradigm shift in information systems auditing. Managerial Auditing Journal, 24(4), 352-367. http://dx.doi.org/10.1108/02686900910948198

McKee, T. (2000). Accounting/auditing technology in Norway: An investigation of the Norwegian accounting/auditing professional knowledge and views on information technologies. Norwegian Institute of Public Accountants (DnR), Oslo, Norway.

Moorthy, M., Seetharaman, A., Mohamed, Z., Gopalan, M., \& San, L. (2011). The impact of information technology on internal auditing. African Journal of Business Management, 5(9), 3523-3539. http://dx.doi.org/10.5897/AJBM10.1047

Moradi, M., Salehi, M., \& Abdlollahian, J. (2012). A study of the audit information technology usage and perceived importance by auditors in Iran. Pacific Business Review International, 5(4),1-14.

Okab, R. (2013). The importance of professional specialty of external auditor in accounting information systems for providing auditing services in information technology environment -A field study in the Jordanian banks. European Journal of Business and Management, 5(7), 207-220.

Pinar, I., Mehtap, O., \& Erzengin, E. (2012). The effect of end user perceptions of information technologies on the information sharing. Journal of Global Strategic Management, 11(June), 32-41.

Prosch, M., McKee, Th., \& Quick, R. (2008). A comparison of the information technology knowledge of United States and German auditors. The International Journal of Digital Accounting Research, 8(14), 45-79. http://dx.doi.org/10.4192/1577-8517-v8_3

Rosli, Kh., Yeow, P., \& Siew, E. (2012). Factors influencing audit technology acceptance by audit firms: A new I-TOE adoption framework. Journal of Accounting and Auditing: Research and Practice, 212, 1-11. http://dx.doi.org/10.5171/2012.876814

Salehi, M., \& Husini, R. (2011). A study of the effect of information technology on internal auditing: Some Iranian evidence. African Journal of Business Management, 5(15), 6169-6179. http://dx.doi.org/10.5897/AJBM10.1013

Strong, J., \& Portz, K. (2015). IT knowledge: What do accounting students think they know? Do you know more than I do? An exploratory study. Review of Business Information Systems, 19(2), 39-50. 
http://dx.doi.org/10.19030/rbis.v19i2.9500

Tumi, A. (2014). An investigative study into the perceived factors precluding auditors from using CAATs and CA. International Journal of Advanced Research in Business, 1(3), 2-11.

\section{Copyrights}

Copyright for this article is retained by the author(s), with first publication rights granted to the journal.

This is an open-access article distributed under the terms and conditions of the Creative Commons Attribution license (http://creativecommons.org/licenses/by/4.0/). 